\title{
TransOceanik Links: Research Networks and the Space-Place of Colloquia
}

\author{
Dr Anita Lundberg \\ James Cook University Australia, Singapore Campus
}

\begin{abstract}
Thinking through network theories (network science, actor-network theory, rhizomatics) and the phenomenology of space and place, this paper argues for the significance of academic research networks and their meeting spaces-places in the 'public domain' of colloquia.

In the global neoliberal education landscape of university rankings, institutions wishing to become research rich need to provide the infrastructure, funding, time and recognition for their academics to build critical mass under strategic research themes, to develop international research networks, and to come together in the public domains of academic symposia, colloquia and conferences in order to incubate ideas and produce scholarly inspired, richly specific, and critically analysed publications.
\end{abstract}

Adapting the practice of a multi-sited ethnographic approach with network mapping, this paper takes as its case study the Laboratoire International Associé (LIA) TransOceanik. It outlines the international networks of LIA TransOceanik and the series of symposia, colloquia and conferences that maintain its transoceanic links between researchers and ideas.

A rhizome may be broken, shattered at a given spot, but it will start up again on one of its old lines, or on new lines. You can never get rid of ants because they form an animal rhizome that can rebound time and again after most of it has been destroyed.... There is a rupture in the rhizome whenever segmentary lines explode into a line of flight, but the line of flight is part of the rhizome. These lines always tie back to one another. - Gilles Deleuze \& Felix Guattari

"Not preconceived notions, but the idea of free thought." ～- Maurice Merleau-Ponty

\section{NETWORK PHENOMENA \& MATRIXIAL SPACE}

\footnotetext{
$\mathrm{A}$ ny university that wants to become research rich, in quality as well as quantity, would be wise to address the underlying intricacies of research practice as networks. Academic research networks and their meeting-places, such as symposia, colloquia, conferences and think-tanks, are the rich spaces in which ideas are imagined, projected, circulated and crossfertilised, co-becoming through interactions, interpretations and display. From these
} 
processes emerge products in the form of publications which, in turn, make new network clusters through citations and indexing.

As the world entered the new millennium, so too did new network science. Developing out the space-place of physics and mathematics, network science demonstrates the properties and process of networks across multiple plateaux from cosmos to brain functions, from the worldwide web to diasporas, from telecommunications to food networks, from ecology to postFordist manufacture, from viruses to global cities, and more (Barabási, 2003; Watts, 2003; Buchanan, 2002).

Recently, network science has been taken up in the humanities and social sciences in diverse projects, from mapping the international flow of magazines across the Pacific during the 1920-1930s golden age of passenger liners, to analysing the phenomenological experiences of students on international exchange through a reading of their blog posts (c.f. Kuttainen et al., 2013; Lundberg et al., 2012). It has also formed the basis of a first year interdisciplinary Bachelor of Arts subject at James Cook University which, as part of its assessment, produces mini case- studies of networks which, in turn, contribute to more network scenarios (Kuttainen \& Lundberg, 2010-2013). The same properties of networks are at work in the very practices of academic research. The LIA TransOceanik research network is a case in point.

Although network science has brought an invigorated impetus to the study of network phenomena, it needs to be understood in relation to the long anthropological, philosophical and animist notions that life is lived and experienced through webs or ecologies of relations. This has been seen in the anthropological-interdisciplinary work of Bateson's ecology of mind project, which wove early systems theory and cybernetics with the humanities as well as social and behavioral sciences $(1972,1979)$. It has been demonstrated through ActorNetwork Theory (ANT) which comes out of the inter-discipline of science studies and employs an ethnographic methodology to study field sites - from scallop fisheries, to scientific laboratories, to manufacture - in order to demonstrate how scientists, practitioners, publics, animals, plants, technologies, writings, spaces and places are all actors in networks of research. In turn, Actor-Network Theory has been taken up by anthropologists to demonstrate that ANT, rather than being endlessly open and traversing domains, is simultaneously an holistic practice, producing its lively research worlds by eliding 'other' domains. In effect, it creates invisible gaps that separate domains (Tsing in Otto \& Bubrant, 2010).

Yet, such gaps are not empty; they are full of potential. They form the interstice from which a new vector of research may suddenly emerge, as it did for Tsing in her imaginative leap from scallops to the matsutake diaspora. Actor-Network Theory, in turn, resonates with Deleuze and Guattari's (1980) network philosophy of rhizomatics - suggesting a post-ANT becoming act-ANT rhizome. And in yet another turn, rhizomatics, from its nascent conception, was influenced by the specifics of ethnographic fieldwork - from the space and place of Indigenous Australian song-lines that arise through particular Aboriginal peoples' Dreaming and articulations through song, dance and ritual (Glowczewski in Alliez \& Goffey, 2011; see Guattari, 1995; 2000).

Notions of space and place are tied up with networks. The space-places of ethnographic fieldwork give nuance and detail to the intricate workings of networks. Thus, studying the particular gives rise to understanding larger patterns. Simultaneously, the macro pattern that network science offers can help us map the entangled patterns of the particular. Like fractals, 
the pattern is repeated within the pattern within the pattern - each the same, but just a little different (Mandelbrot, 1983). Fractals are adept at moving in both directions, microscopic and telescopic, as well as transiting across plateau: lines of flight that link to other disciplinary and classificatory domains. Or, to reiterate the famous question posed by Gregory Bateson: "What is the pattern that connects the crab to the lobster and the orchid to the primrose, and all four of them to me? And me to you?" $(1979$, p. 8$)$.

Likewise, the phenomenology of space and place is not anathema to network theories. An understanding of networks gives us a way of moving from the emptiness of Euclidean geometry to experiencing space - from cosmos to quanta - as alive and resonating, networked through and through. This is suggestive of Merleau-Ponty's notion of the intertwining, the chiasma, where he fuses together science, the body and perception in a radical attempt to rethink the workings of the world and the human encounter with and in it, envisaging the world as animate and humans as being called forth through their environment (1968, p. 147; Lundberg, 2008, p.1). It also evokes Fritjof Capra's exploration of Buddhist, Taoist and Hindu senses of resonating space and their parallels with quantum physics (Capra, 1975). This notion also resonates with Gaston Bachelard's poetics of space: the embodied, affective qualities of space and its creative potential for the imagination (1969 [1958]). In my own writings, this has been taken up as 'material poetics,' where ethnographic encounters with material culture become the exploration of the relation between the material world of artifacts, the environment and bodies and the poetics of metaphor, creativity, imagination, dreams and mystery (Lundberg, 2008).

Theorists of living space maintain that space and place, rather than being separate and in binary opposition, are in relation. This notion was explored by the human geographer $\mathrm{Yi}-\mathrm{Fu}$ Tuan (1977), who also articulates space and place as movement and pause. More recently, Doreen Massey (2005) in her geography of mind and imagination argues that spatial flows form nexuses, demonstrating place as clustered intersections. Places are not existing of themselves; they are complex meeting-places of flows of people and stuff, of entangled histories and stories, of ideas and disagreements, meeting places of difference. This is an imaginary of space and place as interdependent and co-existing (Lundberg et al., 2012, p.11).

All these senses of space are matrixial. As its etymology suggests, matrixial space evokes qualities of the womb and also the medium of a petri dish. A matrix is a substance or situation that disappears into the background as something else emerges (Lundberg et al., 2012, p.12). New ideas may be born or, viral-like, spring forth from this matrix. In this way, the matrix forms webs of significance that break the bounds of the actual bodies in one place. The coming together of researchers and their ideas in time-space-place forms an excess. This is the Durkheimian idea of effervescence: the sum is more than its parts. And yet this holistic imagery is also never ending, the sum never reached. It forms a line of flight, a link to another cluster of researchers bundling and unbundling ideas, perhaps to a former time and the 1903 colloquium at the Ecole des Hautes Etudes Sociales that hosted the debate between Durkheim and Tarde, or its reenactment staged by Frédérique Ait-Touati at the Colloque de Cerisy 'Empirical Metaphysics' in 2007, or again played out at the CRASSH conference in Cambridge in 2008 and then filmed by Martin Pavlov in Paris (www.bruno-

latour.fr/node/354). Just as likely, a link may lead to the deep and cluttered network of contemporary citation indexes. However, what effervescence does demonstrate is that reductionism, the counting of mere parts (publications, citations), is an inadequate accounting system that hides the processual phenomena and intricate relationality of research. 
The LIA TransOceanik network of scholars, and the space-place of symposia, colloquia and conferences that bring members together to incubate ideas and produce publications, is a case study of this larger phenomenon of how networks and matrixial space-places can be used to map the relational processes of academic research.

\section{KNOWLEDGE PLACES \& FLOWS}

\section{Symposia, Colloquia, Conferences}

The notion of bringing academics together in order to share ideas, form new links, incubate knowledge, and produce publications has a long history. In the western tradition this is traced back to the Greek symposium. (In turn, the linked networks of Wikipedia are an appropriate resource for researching an overview of symposia - and colloquia).

The term symposium derives from the Greek, 'to drink together,' and certainly the symposium was a drinking party. Symposia are portrayed in Greek poetry, art and literature. Descriptions of the symposium appear in two of the literary works of the Socratic dialogues. These dialogues are each set in a symposium - Plato's Symposium and Xenophon's Symposium.

The scene of Plato's Symposium is in the house of one of its members in the city of Athens. It comprises a series of lengthy speeches in praise of love and is famous for Socrates' speech where he eloquently argues that the highest purpose of love is to become a philosopher: literally, a lover of wisdom. Xenophon's Symposium is a dramatic piece set at a drinking party in $421 \mathrm{BCE}$ which portrays the discussions of Socrates and other thinkers. In contrast to Plato's Symposium, Xenophon's is full of witty repartee.

Both these written pieces give modern scholars a sense of the intellectual life of ancient Athens and of the practice of the symposium as an institution. Symposia were hosted at different members' houses. Each involved a different topic for discussion, with the participants forming both audience and making presentations. Symposia were noted not only for their intellectual discussions, but also for their conviviality - socialising, music, dancing, jokes, concubines and copious amounts of eating and drinking. The term symposium may also refer to a collection of writings on a particular topic. In this regard both Plato's and Xenophon's Symposium could be imagined as the publication of two symposia. As the Greek tradition spread and was taken up by Roman society, the equivalent to the symposium was the Latin convivium or conversation, from colloqu to talk together. This gives us the contemporary term colloquium.

Today, symposia and colloquia continue the tradition of an intellectual meeting for the purpose of an exchange of ideas and views. They remain a series of academic meetings, moving from one place to another, setting a thematic scene through a specific topic and led by a different convenor or convenors at each meeting. Participants continue to form both the audience and the presenters.

Obviously the notion of the symposium or colloquium is strongly related to that of a conference. However, conferences are usually large, with parallel panels and a broader topic under which are arranged subtopics. Thus, a conference implies a more structured and hierarchical setting. Nevertheless, the aim of both symposia-colloquia and conferences is to 
bring together people and scholars with the same interests to discuss their projects and theoretical views. Although the presentations and discussions are quite formal (occasionally there is an outstanding participant who takes to the tradition of Xenophon and the audience is entertained by some witty and sharp parody of academic interest or academia itself), they are also interspersed with social events and eating and, yes, as the tradition implies, drinking (depending on the specifics of place, the traditions and religions).

More than just an historical association, academic symposia, colloquia and conferences continue the practice of conviviality and sociality. For this practice has a purpose, one especially resonant with the notion of Durkheimian effervescent. As my students are quick to figure out, effervescence is like the bubbles of champagne. When the champagne cork is popped, bubbles overflow the glass; they create more. Hosting people together in one place, over one topic, during an intense period of time, creates effervescence: ideas in flux 'bubbling over with growth and invention' (Holmes, 2009). However, this effervescent flux has come under surveillance as academic research is strictly measured through details of performance indicators and publication points incorporated into, and disciplined though, the neoliberal schemata.

The practice of coming together to share knowledge in various places is likewise a tradition of Eastern knowledge practices. In Hindu and Buddhist traditions spiritually learned men and women are known as gurus. The dialogue between guru and disciples has been an important component of these traditions, often depicted in paintings as the guru sitting under the spreading branches of a bodhi tree in a park surrounded by his or her students. The Hindu tradition is noted in the Upanishads (c. 2000 BCE), the Mahabarata of the Bhagavad Gita, and in the Ramayana. In Buddhist traditions the guru is regarded as a Bodhisattva, the embodiment of the Buddha. This is evident in the Tibetan tradition where lama means 'guru'. Thus a guru is considered to embody knowledge.

Gurus created a network of trails as they travelled from place to place, park to park, tree to tree. These learned men and women may have taught under the shade of the arbor, but their teachings were far from aborescent. As teachings spread widely across countries and oceans, new gurus and hybrid teachings sprang up.

The term guru eventually entered eastern learning traditions and is formalized in schools and education institutions from India to Indonesia where the term refers to a teacher. Similarly, many of the words associated with the ancient lovers of wisdom of the western tradition, including the terms philosophy, symposium, colloquium, have been incorporated into the university academy.

\section{Universities}

In both the east and west, these practices of coming together in various places of thinking and knowledge sharing became more formalized. Rather than a network of different places, the dissemination of knowledge settled into the nexus of the proto-universities.

Eastern proto-universities predate the western university system. Research across the networked sites of the world-wide web indicates that such places of learning include the C5th BCE Taxila or Takshashila of ancient India, now modern-day Pakistan, and the Nalanda in Bihar, India. Archaeological evidence reveals that the Nalanda institute was set in a spacious 
garden of parks and lakes. It had eight compounds and ten temples, including meditation halls, classrooms, a nine-story library, dormitories housing 10,000 students and accommodation for 2,000 professors. Impressive as these structural elements are, more importantly Nalanda was an international meeting place drawing thinkers from Persia and Turkey, from China, Korea, and Japan and as far as Indonesia (Wikipedia). China also had an ancient imperial academy, the Taixue, which was established during the Han Dynasty. Much later, this academy became the Imperial University of Peking and is today known as Peking University. Likewise, some of the many Madrasahs of the medieval Islamic tradition also developed into autonomous universities. A mosque founded in 859 by the female scholar Fatima al-Fihri developed into a university for natural sciences. The University of AlKaraouine in Morocco is argued to be the oldest degree-granting university in the world. It predates the University of Bologna, which formed in 1088. Commonly cited as the 'first' university, Bologna was the first higher education institution to call itself a university. From this time on, universities flourished in Europe and across the world. The term was the conjoining from the Latin versus, 'turned towards,' and uni, 'the whole' (University website). Thus, the term university connotes notions of holism, a world unto itself, although simultaneously it is suggestive of an outward, open gaze.

This particular conception of the university as a place unto itself, walled off, has not been without ruptures. A case in point is the university of Oxford, which was the first university to be established in England around 1096. In 1167 King Henry II banned English students from attending the University of Paris, culling student and academic exchange and mobility. With scholars unable to seek a trans-continental education, they stayed at home, causing a rapid increase in Oxford University's numbers. However, in 1209 a group of professors and scholars broke from Oxford to create Cambridge University. These movements are suggestive of national and international networks - not only their links, but also breakaway vectors that form new clusters (various sites Wikipedia).

Universities as institutions of learning in one fixed place, with their building edifices reaching skywards, bring forth images of trees. But learning is no longer taking place in the shade of various Bodhi trees in different locations, but within hierarchies striving simultaneously for pinnacles and the deep roots of tradition, creating dualisms of professors and students and axial branches of science and mathematics, humanities and social sciences, law and business.

The university of the present is no longer a rigid, enclosed place. A university is a nexus in a networked flow. Universities act as international meeting places, drawing professors and scholars from around the world into spaces of thinking while academics simultaneously transgress university boundaries, forming links with other researchers that allow for spaces of thinking that bring people together based on the sharing of ideas.

This practice can be seen in learned and academic societies. These social gatherings comprise scholars and thinkers who present their work in progress to each other.

\section{Learned and Academic societies}

In the Renaissance period of the C15th humanistic societies developed outside the universities. Europe witnessed hundreds of societies in literary and fine arts, and later in the sciences. Some 700 early 'Renaissance' societies were formed by the sixteenth century, 
mostly in Italy, and 2,500 societies developed between the seventeenth and nineteenth centuries (McClellan, 2003). Renaissance societies were like rhizomatic roots, spreading in numerous directions, taking interest in the many fields of arts, literature and sciences, popping up in many places.

However, many of these gatherings eventually became formalized with membership restricted to practitioners or theorists in specialised fields, usually requiring endorsement by established members, and these became known as academies. The first such academy is thought to be the Royal Society of England founded in 1660, and by the 1700s both learned societies and academies were spreading rapidly across Europe (McClellan, 2003). The space of these linked networks of societies and academies provided the forum in which academics could present work and they were extremely important in their function of publishing and disseminating ideas, a function now predominantly taken over by another academic cluster: publishing houses and journals. Learned societies, and especially the formal academies, also sponsored research projects.

While membership of learned societies and academies continues to be held in high esteem, such membership remains difficult to attain as these groups have continued to develop into large, formalized organizations, often specialized according to disciplines. In other words, from a spread of thinking networks they have set down tap roots and sprouted trunks, creating a sense of stability and hierarchical growth. In fact, several learned societies and academies eventually became national institutions.

\section{Research Organisations}

The interwar period of the 1920-30s saw the intensification of transoceanic travel, the rise of city skyscrapers, and also the rise of national research agendas and the concomitant creation of centralised scientific research organisations. This intensification of research grew as nations became embroiled in WWII.

Le Centre National de la Recherche Scientifique (CNRS) was created on October 19, 1939 by Presidential decree. The main administration and many centres are located in Paris, but centres are also spread across France and eleven are located in other countries and across oceans. CNRS forms the largest governmental research organisation in France. It is also the largest research organization in fundamental science in Europe. However, the organisation is not limited to science: it includes humanities and social sciences as one of its ten institutes (www.cnrs.fr).

CNRS has both independent research units and those that run in association with other institutions and universities. In the French tradition, these administrative unités de recherche are informally referred to as laboratoires. Each laboratoire is headed by a director who may be either a CNRS research director, or a university professor. Laboratoires that are in partnership and linked with other universities, research institutions, research groups, or industry, are referred to as unités mixtes de recherche (www.cnrs.fr). Mixed research groups, in fact, comprise a majority $85 \%$ of the approximately 1,260 CNRS research laboratoires. These linked research groups reside in an interesting space-place. While still held within the matrixial space of the CNRS, unités mixtes often shelter in other places, either within universities or their associated research institutions. 
The CNRS networks for cooperation in research, including formal agreements between institutions and researcher exchanges, number approximately 700 . These international cooperatives are in the form of bilateral conventions such as: International Programs for Scienific Cooperation (PICS), International Research Networks (GDRI) International Joint Units (UMI), as well as LIAs. In 2011 CNRS reported 127 LIAs (www.cnrs.fr).

The prevalence of these linked laboratoires is a noted characteristic of the French research system. This conception of research as inherently networked is suggestive of a cultural research practice informed by the prevalence in the French philosophical tradition of network theories: from Saussaurian linguistics, to Levi-Straussian anthropology and its structural analysis of mythology and genealogy, to Latour and Callon et al.'s Actor-Network Theory (ANT), to Deleuze and Guattari's rhizomatics.

The LIA TransOceanik is just one fractal, or cluster, of this large and complex network. However, this smaller case study constantly links back into the larger network. Both are constantly at work, crisscrossing, flowing, forming connections and ruptures.

\section{LIA Laboratoire International Associé}

LIAs (Laboratoire International Associé) extend research links to cooperation on a joint project between one or more French teams and a main partner in another country. Research teams that already have joint publications can formalise their collaboration by applying for a LIA - also referred to by CNRS as a 'laboratory without walls' (www.cnrs.fr).

The bilateral research networks formalise their relationship link through a contract signed by the heads of the research teams' organizations. Through this agreement, a nexus of material and human capital for the project is created while each research team simultaneously maintains autonomy, status, directors and their various locations. Thus the LIA itself is a node - a space without walls - that draws to it flows of people, materials and ideas.

The research activities of the LIA are coordinated by two co-principal investigators. The French co-principle will be a CNRS researcher or a Professor of a CNRS-affiliated research unit. The foreign co-principle will be a Professor from a research organisation, institute or university. Laboratoire International Associé are part of CNRS's commitment to forging international research links through co-research, the sharing of research, and international copublications (CNRS, 2013, p.33).

Seven cooperative international research networks have been formed between CNRS France and Australia. Significantly, LIA TransOceanik is the first International Associated Laboratory to bring together both France and Australia in research in the humanities and social sciences.

\section{LIA TransOceanik}

LIA TransOceanik was formally recognized in January 2012 as a laboratoire for cooperation in research between the CNRS France and James Cook University Australia, including its offshore campus in Singapore. The LIA is co-directed by the research professors Barbara Glowczewski and Ton Otto. Glowczewski is Director of Research at CNRS, and a member of LAS Laboratoire d'anthropologie sociale, which was founded in 1960 by Claude LéviStrauss. The LAS is a joint project between the Collège de France, the EHESS (École des 
Hautes Études en Sciences Sociales), and the CNRS. Otto is the 'Tropical Research Leader' at The Cairns Institute (TCI) who heads the research cluster of 'Peoples and Societies of the Tropics'; he is also the founder of the 'Culture, Agency, and Change' research group. The Cairns Institute (TCI) is the tropical research institute in Arts, Education and Social Sciences, as well as Law, Business and Creative Arts at James Cook University(JCU), serving its three tropical campuses located in Cairns and Townsville, Northern Australia, and in Singapore.

The LIA TransOceanik brings together thirteen French anthropologists from the LAS Laboratoire d'anthropologie sociale, an interdisciplinary team of researchers from the Arts and Social Sciences of James Cook University (JCU), and twenty PhD candidates and postdoctorial fellows (CNRS, 2013, p. 33). These researchers come together under the theme of 'Interactive research, mapping, and creative agency in the Pacific, the Indian Ocean and the Atlantic'. The LIA TransOceanik's broad mandate is the people and places of the tropics, including the various social, cultural, political and creative responses of particular groups of people to discrimination as a result of colonialism and post-colonialism (CNRS 2013, p. 33).

A discussion of the symposia, colloquia, conferences and exhibitions with which LIA TransOceanik has been associated demonstrates that the LIA forms out of this matrixial space of networks of research and, furthermore, it is involved in lines of flight that link the research, research groups, centres and institutes in a fine web of relations that transport ideas across the oceans of the Pacific, Indian and Atlantic.

These links include those of LIA outlined above - LAS, CNRS, Collège de France with TCI, Culture, Agency and Change research group, the School of Arts and Social Sciences, and JCU. However these links create lines that leap to other places, creating new networked spaces. Direct lines formed through the TransOceanik colloquia to other research groups include: Aarhus Universitet, Denmark, and Universitetet i Bergen, Norway; as well as the Laboratory Textes, langues, communications dans les espaces créolophones et francophones (LCF) and the Observatory of Societies of the Indian Ocean (OSOI) of the Universite de la Réunion; and in another line, which crosses the previous one, with the Programa de PósGraduação em Antropologia Social PPGAS and the Centro de Filosofia e Ciências Humanas (CFH) of the Universidade Federal de Santa Catarina (UFSC), Florianopolis; as well as the Associaçāo Brasileira de Antropologia (ABA).

These links, if appreciated from a panoptic view or 'far reading,' demonstrate networks. However, this view gives little sense of the space-places from which links and lines emerge. Each space-place of a TransOceanik seminar, colloquia, conference or exhibition produces further relations of researchers and ideas. The network is comprised of clusters within clusters, like the infinite pattern of fractals, and each cluster has the potential to create a new line that links to another cluster. These lines are formed through peoples and places, researchers and collaborations, research topics, ideas, research groups, exhibitions, presentations, publications, technologies, and field locations, as well as emails and transoceanic flights.

\section{TransOceanik Currents}

Following the currents inherent in the name TransOceanik, the meetings of the research group have been held through symposia, colloquia and conferences on the Pacific rim in Cairns, Australia, in the Indian Ocean at Saint-Denis on the island of La Réunion, and on the 
edge of the Atlantic Ocean in Florianopolis, Brazil. A colloquium in Paris drew together transoceanic collaborators from each of these ocean locals and further. These transoceanic locations, like the research spaces the scholars engage, lie in the tropics.

Although the LIA TransOceanik was formalised in January 2012, the application process for a Laboratoire International Associé relies on prior co-operation and publication between a research group in France and a group in Australia. Thus, the cartography of TransOceanik links ripples outwards, transgressing official dates and hierarchies of order.

\section{Pacific}

\section{The Cairns Institute, Cairns, July 2010}

A proto-TransOceanik colloquium was held in Cairns in July 2010. Entitled Ethnography: Interactive Research and Reciprocity, it was organised by Ton Otto and Rosita Henry of the 'Culture, Agency, and Change' Research Group of The Cairns Institute (TCI) in collaboration with Barbara Glowczewski, Directrice de recherche, CNRS, Paris.

The colloquium brought together researchers with expertise in peoples and societies of the tropics, including the regions of the Amazon in South America, Papua New Guinea, Indigenous Northern Australia, the Pacific Islands and South-East Asia. Papers from this colloquium recently appeared as a Special Issue edited by Otto, entitled 'Productive Relations and Relational Products: Field Research and Reciprocity' in TAPJA The Asia Pacific Journal of Anthropology, April 2013, linking to a new network of journal editors and academic readers. The collection includes a joint paper by the colloquium coordinators (Glowczewski, Henry, \& Otto, 2013).

The colloquium's publication is an example of how networks form a matrixial space. The colloquium formed a nexus, drawing together a flow of researchers, ideas, digital technologies, research findings and questions. However, this flow also moves outwards via the networks formed through researchers' ideas and the research groups, centres and institutes in which their ideas cluster. Thus, this colloquium linked The Cairns Institute TCI, James Cook University JCU, and the Culture, Agency and Change research group with the CNRS, and further to SOGIP (Scales of Governance and Indigenous Peoples), LAIOS (Laboratoire d'Anthropologie des Institutions et des Organisations Sociales), LAS (Laboratoire d'Anthropologie Sociale), the Collège de France, the EHESS (École des Hautes Études en Sciences Sociales), as well as the 'Pacific Alternatives: Heritage and Political Innovation in the Pacific' research network of Radboud University, further again to the University of Cologne, and also the Australian National University ANU. These are the links that emerge from the few select papers produced in the publication from the colloquium. A cartography of all colloquium participants would produce many more links, as would a fractal analysis of the links within each researcher's links.

\section{The Cairns Institute, Cairns, August 2011}

The following year, in August, 2011, another colloquium was hosted in Cairns on the Pacific Ocean. It was convened by Anita Lundberg, Anthropology, and Nigel Chang, Archaeology, James Cook University.

There were a number of distinctive features of this second colloquium that further opened up the research network. To begin with, it was organised under the auspices of the newly emerging research network TransOceanik Links (the precursor to the formal LIA 
TransOceanik) in collaboration with LAS Laboratoire d'Anthropologie Sociale, CNRS, the Culture, Agency and Change research group of The Cairns Institute (TCI), and the School of Arts and Social Sciences, James Cook University. At this juncture, James Cook University was at the threshold of forming a 'networked university.' Within a couple of months, it would announce the buy-out of its offshore campus in Singapore and embark on a 'tri-city' university culture and rebranding. The colloquium, pre-empting this move, invited researchers from the JCU Singapore campus to join colleagues from the Townsville and Cairns campuses as part of the JCU representatives at the colloquium under the auspices of The Cairns Institute TCI.

In turn, The Cairns Institute was broadening its research profile to include Law, Business and Creative Arts within its research nexus which had, to date, concentrated on Arts, Education and Social Sciences. Thus, this colloquium became more interdisciplinary. Under the theme Academic Research in the Public Domain: Interactions, Interpretations and Display, it brought together researchers from business and law, archaeology, anthropology, arts, tourism, social work, women's studies, English and postcolonial studies, as well as multicultural and indigenous studies. It also received representatives from civic society - including an independent scholar and the Executive Manager of the department of Integrated Sustainability Initiatives of the Townsville City Council, who had recently lead a team on the IBM Smarter Cities Challenge (IBM 2011).

Through the participating researchers' ideas, the host research groups - now clustered via the nascent TransOceanik Links - were further linked to the University of Papua New Guinea and an exhibition at Musée de l'Hospice Saint-Roch, to the Earthwatch Institute, to archaeological digs in Sepon District, Laos and Ban Not Wat, Thailand, to Nakhon Ratchasima Rajhabhat University (NRRU) and Kasetsart Univerity in Bangkok, to the Université de Montpellier 3, to the Integrated Sustainable Initiatives of the Townsville City Council which links to the IBM Smarter Cities Challenge (IBM, 2011), and further to Entropia Universe in cyberspace.

This colloquium had an air of openness and flexibility, encouraging further impromptu research links, including the launch of two books during the event. One of the books was a co-edited collection by two of the TransOceanik founding members, Barbara Glowczewski (CNRS) and Rosita Henry (JCU). The Challenge of Indigenous peoples. Spectacle or Politics? (2011) included chapters from eight members of the emerging LIA TransOceanik. This collection thus creates further links, some creating lines of return and some lines that fling themselves across to the University of Melbourne, the Musée du quai Branly, Paris, the University of Queensland UQ, the ANR Agence Nationale de la Recherche, France, and JustIndia (joint programme on justice and governance in India and South Asia).

Thus, a network map of the Academic Research in the Public Domain colloquium forms clusters and cluster fractals that transit across, at the same time as nestling within, the cartograph of TransOceanik. The matrixial space of the small collection of papers emerging from the colloquium are yet another plateau that can be opened up for exploration. Those papers are collected here in this special edition of Etropics.

\section{Transoceanic}


By the end of 2011, TransOceanik was well advanced in its preparations for becoming an LIA, which was ratified in January 2012. Thus TransOceanik became a formal nexus linking CNRS, Collège de France and JCU through its School of Arts and Social Sciences and The Cairns Institute.

The TransOceanik laboratoire was now involved in numerous specific research projects, many cross-projects, as well as continuing to organise further international symposia and colloquia. These events all extended links with other researchers, research groups, institutes, publics and the space-places of research practice from fieldwork sites to archival deposits, to conferences and exhibitions.

\section{Musée du quai Branly, Paris, December 2011}

In December 2011 an international colloquium, Mémoire heureuse, héritages douloureux: des lieux, des arts et des jeux, was held at the Musée du quai Branly (MQB), Paris. It was organized by Barbara Glowczewski and Aïda Kanafani-Zahar of the Anthropologie de la Perception group of the Laboiratoire d'anthropologie sociale (LAS, Collège de France).

An audiovisual of the MQB colloquium, including powerpoints and film extracts by Lise Garoud (PhD JCU/EHESS) can be viewed online at AAR (archives audiovisuelles de la recherche):

http://www.archivesaudiovisuelles.fr/EN/Event.asp?id=2174\&url=/2174/home.asp

The Musée du quai Branly colloquium further formed links between the still nascent TransOceanik network with the CNRS's GDRI (International Research Network) entitled Anthropologie et histoire des arts. Bodies of participants themselves form lines, while also establishing a corporality of ideas that link further to research centres and universities, including: IREMAM (Institut de Recherches et d'Etudes sur le Monde Arabe et Musulman), Université d'Aix-Marseille; Université de La Réunion; Comité pour la Mémoire et l'Histoire de l'Esclavage; Goldsmiths College, University of London; Institute for Art Anthropology, Tama Art University, Tokyo; École nationale supérieure de création industrielle (ENSCI); Université de Bordeaux; James Cook University; Université Paris 13; Université de Liège et Université de Louvain; and the Institut interdisciplinaire d'anthropologie du contemporain (IIAC) which is linked back to CNRS and EHESS. In turn, the announcement of the colloquium through the Australian Embassy Newsletter (Dec 7, 2011), forms links between France and Australia through diplomatic relations.

The links of the Musée du quai Branly colloquium create further lines to public researchers outside the place of academia, but very much part of the spaces of research. This colloquium was transoceanic. Drawing on research in cinema, politics, photography, literature, history, war, memory, writing, material culture and people, it encountered the space-places including those of exiles and diasporas - of Rwanda, Palestine, La Réunion, Haiti, Lebanon, Isreal, Japan, France, Palm Island in Australia and cyberspace.

http://actualites.ehess.fr/nouvelle4628.html

\section{North Queensland to France}

Another research project, set on the pacific rim of coastal North Queensland, Australia, links an ARC (Australian Research Council) Discovery Grant with museums in France. As the project notes, the collection of Aboriginal artefacts, such as painted shields and woven 
baskets from the Wet Tropics of Australia, has a long history connected with colonialism and post-colonialism. The aims of the project are to examine relationships between artefact collectors, Aboriginal producers and their descendants, museums and the state. In 2012, two associates of the LAS Laboratoire d'anthropologie sociale were funded to report on North Queensland artefact collections held in France, including: the Anthelme Thozet collections and Archives in the Confluences in Lyon, and the Musée du quai Branly and Musée d'Histoire Naturelle in Paris (Henry, Dec 2012). The lead investigators on the ARC grant, entitled Objects of Possession: Artefact Transactions in the Wet Tropics of North Queensland, 1870-2013, are from the School of Arts and Social Sciences (anthropology, archaeology and history) at James Cook University (JCU) and are linked to the Culture, Agency and Change research group of The Cairns Institute (TCI). Many are also members of LIA TransOceanik.

\section{A Pacific return}

\section{Festival of Pacific Arts, Solomon Islands, July 2012}

In July 2012 two LIA TransOceanik members, Rosita Henry (JCU) and Géraldine Le Roux (CNRS, LAS), did joint fieldwork at the $11^{\text {th }}$ Festival of Pacific Arts. The festival was held in Honiara, the Solomon Islands, under the theme 'Culture in Harmony with Nature'. This festival is an important event that intertwines postcolonial politics and creative performance. The event is held every four years and maintains networks between countries and island nations across the Pacific (CNRS 2013 p.33).

The festival was inaugurated in 1972 to encourage the retention of traditional cultural practices by sharing and exchanging culture. Each festival is hosted by a different nation in the aim to recognise the specific Indigenous culture/s associated with each place as the space of the festival travels across the Pacific. The festival links peoples and forms clusters of regional identity, while also creating a nexus that draws together Pacific-wide culture.

Since the inaugural festival, delegations from twenty-seven Pacific Island Countries and Territories have participated, including: American Samoa, Australia, Cook Islands, Easter Island, Federated States of Micronesia, Fiji Islands, French Polynesia, Guam, Hawaii, Kiribati, Marshall Islands, Nauru, New Caledonia, New Zealand, Niue, Norfolk Island, Northern Mariana Islands, Palau, Papua New Guinea, Pitcairn Islands, Samoa, Solomon Islands, Tokelau, Tonga, Tuvalu, Vanuatu and Wallis and Futuna. In 2008 Taiwan joined. The 2012 Pacific Festival hosted 2,500 delegates from 26 Pacific countries. (ABC Radio Australia, 18 July 2012).

Indigenous festivals intersect memory and modernity; they involve the performance of place, including the mixed spaces of Indigenous and non-indigenous crossings. The 1970s were not only a time of inauguration of festivals, but also saw a wave of 'counter-culture' movements. Along the pacific north coast of Australia, colonies of hippies moved into rural communities inhabited by Aboriginal people. The town of Kuranda in North Queensland was one such place. Rosita Henry's book reminds us that the acts of Performing Place, Practising Memories (2012), happen in the everyday as places become sites of 'linked social dramas that portrayed the use of both public and private space'.

\section{The Cairns Institute, August 2012}


In August, 2012, James Cook University was the host for the first official LIA TransOceanik international colloquium. The Cairns Institute (TCI), in collaboration with the Aarhus University, Denmark, and University of Bergen, Norway, brought together researchers under the theme: Values of Dominance and Difference - An exercise in critical social science and design. The colloquium was organized by Ton Otto (JCU), Steffen Dalsgaard (Aarhus Universitet, AU), and Bruce Kapferer (Universitetet i Bergen, UiB). It included thirty participants, of which eleven were members of LIA TransOceanik.

Through this meeting, the TransOceanik network of researchers was linked not only with Aarhus and Bergen Universities in Scandinavia, but also further to the Université FrançoisRabelais, Tours, France; the Australian National University (ANU); the University of Manchester, UK; Virginia Tech (USA and international locations in Switzerland and the Dominican Republic); Griffith University, Queensland; and North Karelia University of Applied Sciences, Finland. The research interests of the colloquium participants created network tendrils through tropical locations from Northern Australia and across Oceania, to Mozambique, Eastern Indonesia, Sri Lanka, and Melanesia.

Through the bodies of various participants, there is a line that links back to a previous colloquium at the Musée du quai Branly, Paris, and again, to the ARC Grant on the artefacts of the wet tropics of North Queensland. Other links transport over to new territories. For example, one line leaps across to the Documentary Education Resources (DER), a repository of cross-cultural film for educational use, which links further to the Human Studies Film Archives of the Smithsonian Institute. A similar line leads to the Moesgård Museum, Aarhus, Denmark, and to the International Migration and Ethnic Relations (IMER) research group of University of Bergen and the Western Solomons Research Database (which, in turn, forms a cluster of North Karelia University of Applied Sciences, the University of Bergen, and the Western Province and Solomon Islands Ministry of Education and Human Resources Development). Yet another line leads to the research group on the Domestic Moral Economy (DME) of Asia Pacific (which clusters the universities of Manchester, Belfast and the Australian National University, as well as to the ESRC Economic and Social Research Council, UK). A further line links to the non-profit organisation VolunTourism (www.voluntourism.org).

\section{Indian Ocean}

\section{Université de la Réunion, September 2012}

In the year of 2012, LIA TransOceanik was also involved in an international conference on the Island of La Réunion, a French département d'outre-mer DOM, in the Indian Ocean. The conference theme was entitled 'Between Creolization and Indigeneity: Ambiguous memories and creative responses in the Tropical worlds (Indian, Pacific, Atlantic Oceans)'. [Entre créolisation et autochtonie: mémoires ambigües et réponses créatives dans les mondes tropicaux (Océan indien, Pacifique, Atlantique)] http://www.lcf-reunion.fr/colloqueinternational-entre-creolisation-et-autochtonie-memoires-ambigues-et-reponses-creativesdans-les-mondes-tropicaux-ocean-indien-pacifique-et-atlantique-3-5-septembre-2012/

The conference was organised by research Professors Carpanin Marimoutou and Barbara Glowczewski. It brought together the research laboratory Textes, langues, communications 
dans les espaces créolophones et francophones (LCF) and the Observatory of Societies of the Indian Ocean (OSOI) of the Faculty of Letters, Universite de la Réunion, with LIA TransOceanik and its cluster of LAS, CNRS, Collège de France and James Cook University. The conference was also supported by the international research group Anthropology and Art History of the Musée du quai Branly, Paris. Half of the participants in this specialised gathering of twenty-four researchers were members of the TransOceanik network.

Once again embarking on following just some of the lines of research ideas and researchers meeting through the space-place of colloquia, this conference leads back to July 2006 and a conference hosted by the Centre for the Study of Colonial and Post-Colonial Studies (CSCPS) at the University of Bristol, UK. www.bristol.ac.uk/colonialstudies/events/postcolonial_literatures/programme

It also creates a line forward to the present and an international colloquium at the Théâtre Claude Lévi-Strauss at the Musée du quai Branly, Paris (www.lcf-reunion.fr). And, further, it links to the 2013 LIA TransOceanik symposium in Brazil.

Yet other lines are flung back again to research groups that have already been encountered in this matrix of the TransOceanik research network. One such line is to SOGIP (Scales of Governance the UN and Indigenous Peoples), which appeared in the first proto TransOceanik colloquium in Cairns in 2010. In turn, SOGIP forms another research cluster as a transdisciplinary global comparative project involving eight countries across four continents and international organisations, including the UN, concerned with the implementation of principles of self-determination for Indigenous Peoples (www.sogip.ehess.fr).

Indigenous self-determination was a central concern of the La Réunion conference which addressed, through multidisciplinary and comparative cases studies, issues relating to colonial memories and creative responses of local peoples across the tropical worlds of the Atlantic, Pacific and Indian oceans. The conference explicitly invoked the imagery of thought of Félix Guattari (2000) concerned with his notion of three ecologies - interconnected networks on the plateaux of mind, society and environment; a theory first expressed by the interdisciplinary theorist Gregory Bateson in Steps to an Ecology of Mind (1972).

The presentations at this conference wove a fine network through places and spaces of fieldwork: Mauritius, La Réunion, Madagascar, New Caledonia, Tahiti and the French Pacific Territories, Fiji, Papua New Guinea, Melanesia, Samoa, Solomon Islands, Brazil, Haiti, Guiana as well as Palm Island, Broome, the Kimberley and the Wet Tropics of North Australia - and further to spaces of film and animation. These places were revealed as simultaneous spaces of memory, heritage, materiality, culture, politics, creativity, gender, diaspora, spirits, festivals, technology and becomings.

There were also new lines, creating new connections and disconnections, with the Cultures and Histories Program of the Queensland Museum, Brisbane, which in turn links to the Museum of Tropical Queensland; another line leads to the School of the Arts and Media at University of New South Wales, Sydney, which creates links between Indian Ocean studies and Indigenous Australian Studies through research agendas as well as through theories from Creolisation to the new Fictocritical Writing and Contingency Theory developed by Stephen Muecke. http://sam.arts.unsw.edu.au/staff/stephen-muecke-777.html 
An audiovisual presentation of the Conference papers will be made available on the website of OSOI (Observatory of societies of the Indian Ocean), of the Université de la Réunion.

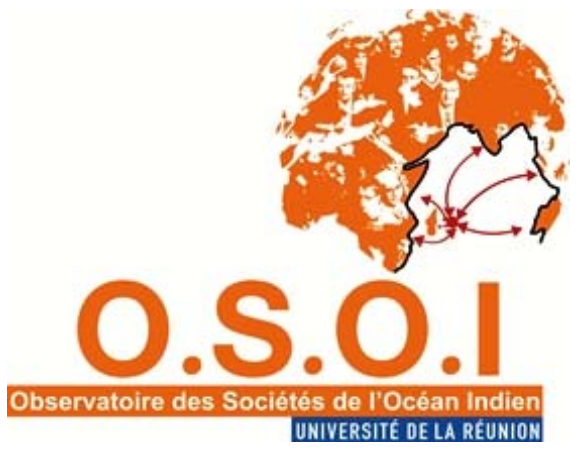

http://recherche.univ-reunion.fr/unites-et-federations/observatoire-des-societes-de-loceanindien/

\section{Atlantic Ocean}

\section{Universidade Federal de Santa Catarina, Brazil, May 2013}

As this special edition of Etropic comes to press, an international symposium is being held in another place, that of Florianopolis, Santa Catarina, Brazil. The matrixial space of the symposium is brought to life through the conceptual imagery of the title 'Blurred Interfaces: masculine/feminine, human/non-human, dead/alive. Questioning norms, classifications and the primacy of language'; [Interfaces borradas: masculino/feminino, humano/não humano, vivo/morto. Questionando normas, classificações e primado da linguagem.]; [Interface troubles: masculin/féminin, humain/non humain, vivant/mort. Questionner les normes, les classifications et le primat du langage.].

The symposium is coordinated by Barbara Glowczewski (LAS-CNRS-France, guest professor at UFSC 2013) with Miriam Pillar Grossi and Felipe Bruno Martens Fernandes (PPGAS/UFSC). Thus, this international symposium links the LIA TransOceanik cluster of LAS/CNRS of France and The Cairns Institute/James Cook University of Australia, with the Programa de Pós-Graduação em Antropologia Social PPGAS, the Centro de Filosofia e Ciências Humanas (CFH) and Nucleo de Identidades de Gênero e Subjetividades (centre for the study of gender identities and subjectivities) (NIGS) of the Universidade Federal de Santa Catarina (UFSC), Florianopolis; as well as the Associaçāo Brasileira de Antropologia (ABA), which is, in turn, celebrating 'expanding frontiers of Anthropological dialogues' over the years 2013-2014.

As the organization for this symposium was in process, Glowczewski was able to report that participants included fifteen academics from different Universities in Brazil and South America, ten French participants and three Australians from James Cook University. (Personal correspondence, 1 April 2013).

The symposium is explicitly concerned with questioning dualisms, and it does this eloquently by bringing together two quotes. One is from Claude Lévi-Strauss where he notes that the study of dualistic structures revealed both anomalies and contradictions, from theory into effect, and he proposes that it would be interesting to treat forms of dualism as surface distortions of structures whose real nature is other, and much more complicated. This is an 
exciting quote that suggests a rupture - an opening. Significantly, this quote is placed next to notes from a seminar by Gilles Deleuze, thus creating resonances that form a new space: a space that I find captures the presentations listed in the symposium outline.

Deleuze, in his quote, is in full flight, encouraging a line of thought, an exploration of a subjective point of view under which heterogenous things are arranged (and possibly dearranged). Rather than seeking the objective view, the kind that by dividing gives a classification of things according to their homogeneity, he proposes to use not classification, but something else: arranging modes of existence.

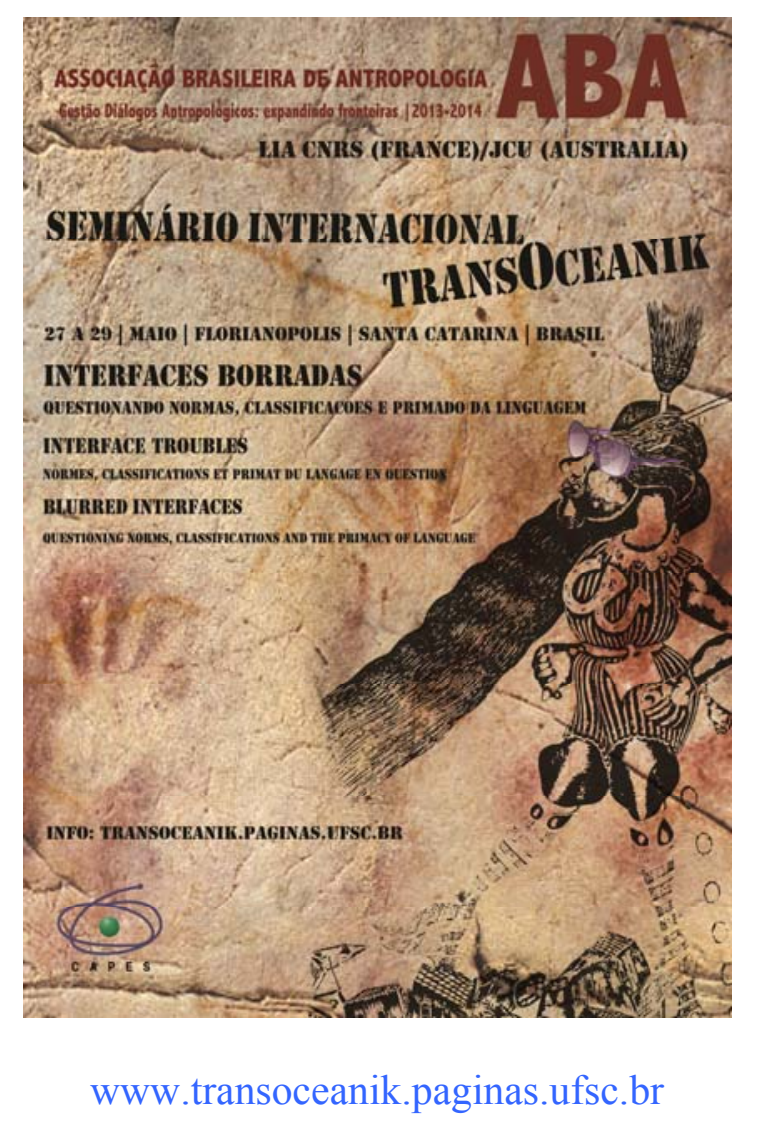

Moving beyond dualism of male/female, human/animal, alive/dead, human/machine to notions of becoming, this LIA TransOceanik symposium is entering transitioning spaces that weave networks between anthropology, psychoanalysis, politics, gender studies, transgenders, feminism, philosophy, experimental film, sign language, technologies, science studies, material culture, history, ritual, ruins, art, memory, indigenous studies, death, radio, spirits, sharmanism, sacrifice, postimperialism, race, neuroscience and psychotropic substances.

These spaces also transect places: Brazil, Cuba, France, Italy, Australia, Argentina, Europe, Mexico and Mesoamerica. Within this international sphere, the symposium works through a matrix of language: Portugese, French, English, and filmed sign language.

\section{GAPS}


This paper set out to map the TransOceanik Links created through research networks and the space-place of symposia and colloquia. Although a revealing exercise, what this paperusing a practice of 'far reading' - cannot achieve is the sense of peoples in specific spaces and places.

In effect, this paper creates a gap between academic research and public domains. An ironic gap, given that the paper seeks to address, within its larger network analysis, the colloquium at The Cairns Institute (TCI) that was hosted under the theme Academic Research in the Public Domain: Interactions, Interpretations and Display. This gap calls to be transgressed, crossed, and it is here that the other papers in this special edition succeed for they fling lines across this chasm through their 'close readings' of specific public domains. Nevertheless, at the same time, each of these papers, in turn, unexpectedly evokes the themes of networks, space and place.

The papers encounter: the liminal space of the 'non-public domains' of Singapore where spirits may arise; reflexive engagement employed by a cluster of researchers in order to cross the space between qualitative and quantitative analysis to understand the complex web of the social domain; a South Sea Islander diaspora in North Queensland and engagement in cultural expression through online social media like Facebook and YouTube; a crossdisciplinary dialectic between two postgraduate researchers exploring digital embodiment and notions of relational selfhood in a liminal community of symbionts, cyborgs, and avatars; the complex conversations and negotiations involved in socially sensitive research which include academics, community groups, civil society, government, industry and other stakeholders; a cyber-ethnographer engaging in the collective and interactive life that exists beyond the confines of the physical realm; and the 'converting' of linguistic materials language, oral texts, traditional song knowledge - from recordings to digital CDs and DVDs to use as educational resources by the Warlpiri community of Central Australia.

In turn, the Warlpiri people, through a rhizomatic thread, return this paper to its beginnings and a conversation between Barbara Glowczewski's and Félix Guattari about her early fieldwork with Warlpiri people. As the young anthropologist in the field tracked from place to place, the Warlpiri were teaching her about their sense of space and place as networked through Songlines and Dreamings. This 'nomadism' inspired the theoretician of schizoanalysis in the making of his fluctuant cartography. This fine link between Songlines and network theories suggests a way of thinking that is simultaneously ancient and thoroughly 21 st century networked. It also demonstrates how the public informs academia: crossing domains, spreading through networks.

\section{Research Rich Universities}

The reality of the $21^{\text {st }}$ century life world, a world that is increasingly global (but by no means flat-earthed) and networked (although with the unevenness of hubs, clusters and blanked out spaces), requires that universities recognise the serious challenge of research in this age of transnational education flows. Universities seeking to become research-rich would be wise to analyse the notions of networks, space and place that form part of their imaginary. More than rhetoric or branding, these concepts are themselves rich in academic practice and philosophical analysis.

Lovers of wisdom have long understood the importance of bringing people together in 
different places, through different hosts and themed topics. Researchers continue this long tradition. Today they do this by crossing oceans in order to create a crossing of ideas. More than any other time, in this time researchers need to engage. They need to forge crossdisciplinary conversations, interdisciplines - in short, TransOceanik Links.

\section{ACKNOWLEDGEMENTS}

As with all writing, the process is never accomplished alone. Even in the quiet, dark, hours of 4 am as I finish this paper, I feel the joy of relations with ideas, with the keyboard and screen, the desk and chair, the breath of the stirrings of the predawn. I am also accompanied by an email sent by Barbara Glowczewski from Brazil, which arrived at midnight, Singapore time, the night before. In the email, Barbara alerts me to the Durkheim-Tarde debate and its academic performances, to the fascinating 'Continental Drift' blog site, and makes several further links that have helped this thinking-writing process.

\section{WORKS CITED}

ABC Radio Australia (18 July, 2012). The art, culture and faces of the Festival of Pacific Arts 2012. Retrieved from http://www.radioaustralia.net.au/international/radio/onairhighlights/the-art-cultureand-faces-of-the-festival-of-pacific-arts-2012/978948

Bachelard, G. (1969 [1958]). The poetics of space. M. Jolas (trans.). Boston, MA: Beacon Press.

Barabási, A. (2003). Linked: how everything is connected to everything else and what it means for business, science, and everyday life. New York: Plume.

Bateson, G. (1972). Steps to an Ecology of Mind: Collected Essays in Anthropology, Psychiatry, Evolution, and Epistemology. Chicago, Ill.: University of Chicago Press.

Bateson, G. (1979). Mind and Nature: A Necessary Unity. (Advances in Systems Theory, Complexity, and the Human Sciences). New York, NY: E. P. Dutton.

Buchanan, M. (2002). Nexus: Small Worlds and the Groundbreaking Science of Networks. NY: W.W. Norton \& Company.

Capra, F. (1975). The Tao of Physics: An Exploration of the Parallels between Modern Physics and Eastern Mysticism. Berkeley, CA.: Shambhala Publications.

McClellan, J. E. III (Ed.) (2003). Learned Societies. In Kors, A. C. (Ed.). Encyclopedia of the Enlightenment. Oxford, UK: Oxford University Press)

CNRS, (January 2013). CNRS international magazine. 28 (Quarterly). Retrieved from: www.cnrs.fr/fr/pdf/cim/28/pubData/SEO/Page_33.html

Deleuze, G. \& Guattari, F. (1980). A Thousand Plateaus. (Vol. 2 of Capitalism and 
Schizophrenia) [Trans. Brian Massumi, 1993]. London \& New York: Continuum.

Glowczewski, B. (2011). Guattari and Anthropology: Existential Territories among Indigenous Australians. In Alliez, É. \& Goffey, A. (Eds). The Guattari Effect. London \& NY: Continuum International Publishing Group.

Glowczewski, B. \& Henry, R. (Eds) (2011). The Challenge of Indigenous peoples. Spectacle or Politics? Oxford, UK: The Bardwell Press.

Glowczewski, B. Henry, R. \& Otto, T. (2013). Relations and Products: Dilemmas of Reciprocity in Fieldwork. The Asia Pacific Journal of Anthropology 14 (2), 113-125.

Guattari, F. (1995) [1992]. Chaosmosis: An Ethico-Aesthetic Paradigm [Trans. Paul Bains and Julian Pefanis]. Bloomington \& Indianopolis: Indiana University Press.

Guattari, F. (2000) [1989]. The Three Ecologies. [Trans. Ian Pindar and Paul Sutton]. London $\&$ New York: The Athlone Press.

Henry, R. (Ed.) (Dec, 2012). Research Project Newsletter 3: ARC Discovery Research in the Tropics. JCU eresearch centre, James Cook University. Retrieved from https://eresearch.jcu.edu.au/spaces/ARCresearch-space/projectnewsletters/newsletter3/at download/file

Holmes, B. (2009) Guattari's Schizoanalytic Cartographies. Continental Drift: the other side of neoliberal globalization. Retrieved from

http://brianholmes.wordpress.com/2009/02/27/guattaris-schizoanalytic-cartographies/

IBM (2011) IBM Smarter Cities Challenge Report - Townsville. Retrieved from www.townsville.qld.gov.au/community/sustainability/Pages/IBM

Kuttainen, V., Lundberg, A. and Law, L. (2013). '1937: The Golden Age of Pacific Travel'. In Telling Stories: Australian Literary Cultures 1935-2012. Dalziell, T and Genoni P. (Eds) Melbourne: Monash UP.

Kuttainen V. \& Lundberg, A. (2010-2013). BA1002 Our Space: Networks, Narratives and the Making of Place. Subject Outline. James Cook University, Cairns, Townsville, Singapore.

Lundberg, A. (2008) Material poetics of a Malay house. The Australian Journal of Anthropology (TAJA), 19 (1), 1-16.

Lundberg, A., Stasiewicz-Bieńkowska, A., \& Enhörning Singhateh, A. (2012) 'Border Crossing Networks: Virtual Reality'. In Fan, S., Le, T., Le, Q., \& Yue, Y. (Eds). Innovative research in a changing and challenging world. (Conference Proceedings) Launceston: Australian Multicultural Interaction Institute. (ISBN 978-0-646-58268-9)

Mandelbrot, B. (1983). The Fractal Geometry of Nature. San Francisco: W.H. Freeman.

Massey, D. (2005). For space. London: Sage. 
Merleau-Ponty, M. (1968). Intertwinings - the chiasm. In The Visible and the Invisible. C. Lefort (ed.), A. Lingis (trans.). Evanston, IL: Northwestern University Press.

Otto, T. (Ed). (2013). Productive Relations and Relational Products: Field Research and Reciprocity. (Special Edition) The Asia Pacific Journal of Anthropology TAPJA. 14 (2).

Tsing, A. (2010). Worlding the Matsutake Diaspora. Or, Can Actor-Network Theory Experiment With Holism? In T. Otto and N. Bubandt (Eds). Experiments in Holism: Theory and Practice in Contemporary Anthropology. Oxford: Wiley-Blackwell.

Tuan, Y-F. (1977). Space and place: the perspective of experience. London: Edward Arnold.

Watts, Duncan.J. (2003). Six degrees: the science of a connected age. New York: W. W. Norton \& Company. 